\title{
Errata Corrige, Thalassemia \\ Reports 2017; 7:6392
}

Editorial Office, Thalassemia Reports, PAGEPress, Italy

Referring to the article: Baiamonte E, Barone R, Contino F, et al. Granulocytecolony stimulating factor plus plerixafor in patients with $\beta$-thalassemia major results in the effective mobilization of primitive CD $34^{+}$cells with specific gene expression profile, published on Thalassemia Reports 2017; volume 7:6392, the following sentence in the Materials and Mehods section is not correct:

(Filgrastim, Amgen, Thousand Oaks, CA, USA).

Corrected sentence must be intended as follows:

[Myelostim 34 F 33,6 33,6 MUI (263 mcg) (Lenograstim), Italfarmaco S.P.A.]

doi:10.4081/thal.2017.7024 